\title{
AN ANALYSIS OF THE NET WORKING CAPITAL MANAGEMENT STRATEGY IN POLISH ALUMINUM PRESSURE FOUNDRIES
}

\author{
Grzegorz ZIMON \\ Rzeszow University of Technology, Rzeszow, Poland, EU, gzimon@prz.edu.pl
}

https://doi.org/10.37904/metal.2019.990

\begin{abstract}
Net working capital management is of key importance for the development of every enterprise. Net working capital directly affects the income, costs, profit and financial safety of business units. It is very complicated to manage it as it concerns the two most important areas from the point of view of short-term management of the current assets and current liabilities. Stocks, receivables from customers, cash or current liabilities in trade, service or production enterprises are managed in a completely different way. Therefore, other strategies for managing net working capital are applied in commercial, service or production enterprises. This is primarily due to the differences that arise in the structure of current assets. The purpose of this article is to present a management strategy for working capital in small and medium production enterprises. For the analysis, 62 aluminum pressure foundries operating in Poland were selected. The analysis was carried out on the basis of the financial statements of the enterprises surveyed, and the research period covered the years 2015-2017. In the article, based on selected enterprises, it was assessed whether the applied capital management strategy model is beneficial for them and, if necessary, in which areas of working capital management changes are necessary.
\end{abstract}

Keywords: Working capital, strategies, aluminum pressure foundries

\section{INTRODUCTION}

Already M.E. Porter noted that "competition in the last decades has increased dramatically in virtually all parts of the world. It appeared in countries where it was not previously [1]. In recent years, after the financial crisis, the financial condition of many enterprises, especially small and medium-sized ones, has deteriorated, and the increased competition in the market has complicated their situation [2-4]. Therefore, in order to counteract it, the managers introduce and implement new solutions whose task is to improve financial results and gain an advantage over the competition. This forces managers to apply modern, efficient financial management systems in two basic areas of business management, current assets and current liabilities, i.e. the areas closely related to working capital. New tools for managing receivables, inventories, liabilities or costs are introduced. Companies merge into group purchasing organizations (GPOs) to take advantage of economies of scale, introduce quality management systems to optimize the level of costs and the level of net working capital.

Working capital management is the basis for building a safe long-term strategy in every company. No matter the size and the branch where they operate. Manufacturing companies operating in heavy industry in particular use completely different strategies that differ greatly from classical strategies. That is why it is very important to develop a working capital management strategy that will allow the company to effectively compete in the market with the competition. The purpose of the article is to evaluate and analyze the working capital management strategy in Polish aluminum pressure foundries.

\section{LITERATURE REVIEW}

Working capital management in the literature is generally associated with two areas - current assets and current liabilities. However, when analyzing the process of working capital management, two further elements that have a direct impact on the level of working capital should be added, namely costs and revenues. Since 
net working capital is the difference between current assets and current liabilities, i.e. this is the part of equity that funds current assets, then a profit will have a very important impact on net working capital will have. The Figure 1 below presents the most important elements of the balance sheet and profit and loss account shaping the level of working capital.

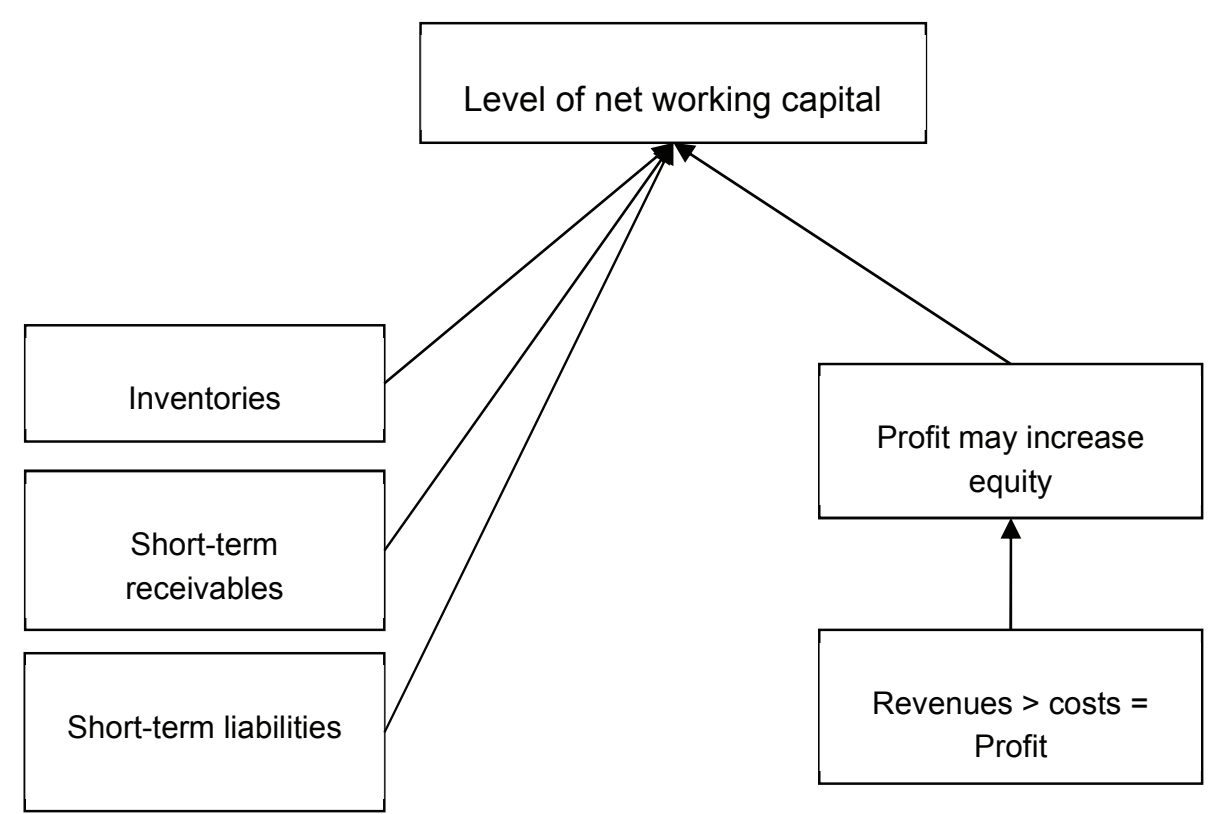

Figure 1 The basic components shaping the level of net working capital

The figure does not include short-term investments, which are very important in the case of managing financial liquidity or working capital. This is due to the fact that in general their share in the structure of current assets, small or medium-sized enterprises is very low. Working capital is an element of management that appears in the management of financial liquidity and the effects of managing it, the selection of an appropriate management strategy also has an impact on financial results. In addition, the impact of working capital management on the productivity, profitability and liquidity of the company has been confirmed in several studies conducted around the Word conducted on various types of enterprises, commercial [5-9], in various industrial sectors, e.g. restaurant and automotive industry [10-11]. The relation between profitability and working capital management arouses great interest among scientists and, for example, in a comprehensive study, document the relationship between the impact of working capital on profitability in US enterprises [12]. This dependence is confirmed by further studies carried out by other authors on the example of Belgian, Greek and small and medium - sized Spanish companies [13-14].

Profitability and financial liquidity are the elements that are noticed by all those interested in financial data of the company, i.e. managers, owners as well as competitors or banks interested in granting loans. It is important that these measures in the company achieve the best possible levels. Managers must, therefore, construct such a working capital management strategy that will enable them to achieve both high financial liquidity and profitability and efficiency of business management.

\section{STRATEGIES OF WORKING CAPITAL MANAGEMENT}

In general, information on three general aggressive, conservative and moderate working capital management strategies can be found in the literature. However, for manufacturing companies, classical strategies should be modified accordingly. Especially for enterprises related to heavy, energy-intensive industries. Such industrial group includes aluminum pressure foundries. Unlike commercial enterprises, they do not only trade in goods. Often only for a specific order. One of the most important cost components in such enterprises is the 
consumption of materials and energy. Therefore, it is worth using the following working capital management strategies for this group of enterprises [15].

- The conservative strategy in manufacturing enterprises will be characterized by a model level of liquidity. Inventories will not unnecessarily inflate financial liquidity ratios, they will not create unnecessary provisions. Their optimal level will have a positive impact on inventory management costs, which will help maintain high profitability.

- $\quad$ The aggressive strategy will not differ much from the conservative strategy. The company managing receivables will surely try to extend the deadlines for their repayment, because the company will want to acquire new contractors with the trade credit. These activities should result in increased sales. The structure of liabilities may significantly increase the level of short-term liabilities. This will be due to difficulties in collecting receivables from customers on time, which may delay the repayment of liabilities.

- The third type is the moderate management strategy for working capital management. This type of management is an indirect strategy between conservative and aggressive. Moderate strategies will be very similar to previous strategies. The moderate strategy of managing receivables from customers is the centering of conservative and aggressive strategies

\section{RESULTS}

An assessment of the level of working capital was made on the basis of 62 aluminum casting houses operating in Poland. The first stage of the analysis was an assessment of financial liquidity in the surveyed companies over the period 2015-2017. Then the basic ratios of financial analysis regarding the area of working capital were used. Descriptive statistics for selected ratios are presented using the following statistical methods: arithmetic mean $(\bar{x})$, median (Me), highest (maximum) and smallest (minimum), standard deviation $(s)$, variation coefficient $(V)$. Table 1 presents a simplified structure of current assets.

The analysis conducted showed that enterprises have positive net working capital, which is confirmed by the results of financial liquidity indicators. Of the analyzed enterprises, only 5 enterprises had low liquidity and negative net working capital. The detailed results for the enterprises analyzed and the financial liquidity ratio are presented in Table 1.

Table 1 The ratio assessment of financial liquidity in the surveyed enterprises

\begin{tabular}{|c|c|c|c|c|c|c|}
\hline Current liquidity & $\bar{x}$ & Me & $\boldsymbol{s}$ & $\min$ & $\max$ & $\boldsymbol{V}$ \\
\hline 2015 year & 1.73 & 1.71 & 0.80 & 0.90 & 3.50 & $47.1 \%$ \\
\hline 2016 year & 1.67 & 1.60 & 0.66 & 0.73 & $3 . .70$ & $38.9 \%$ \\
\hline 2017 year & 1.61 & 1.55 & 0.87 & 0.60 & 5.10 & $53.1 \%$ \\
\hline
\end{tabular}

Source: author's own research

The average results in the analyzed enterprises reach the standard results in the range between 1.6 and 1.7 Another ratio that was examined concerned the operational cycle. The results of the operational cycle in the analyzed enterprises are presented in Table 2.

Table 2 Average results of the operating cycle ratio in days

\begin{tabular}{|c|c|c|c|c|c|}
\hline Cash cycle & $\bar{x}$ & Me & $\boldsymbol{s}$ & $\min$ & $\max$ \\
\hline 2015 year & 86 & 80 & 17 & 65 & 109 \\
\hline 2016 year & 94 & 91 & 25 & 70 & 127 \\
\hline 2017 year & 98 & 94 & 23 & 71 & 132 \\
\hline
\end{tabular}

Source: author's own research 
The results of the operating cycle should be assessed positively because they do not exceed 100 days. The next analyzed ratio concerned the cash conversion cycle. The average results of this ratio should also be assessed positively because the demand for working capital ranges from 26 days to 30 .

Table 3 Average results of the cash conversion cycle in days

\begin{tabular}{|c|c|c|c|c|c|}
\hline Cash conversion cycle & $\bar{x}$ & Me & $\boldsymbol{s}$ & $\min$ & $\max$ \\
\hline 2015 year & 26 & 23 & 11 & 14 & 30 \\
\hline 2016 year & 29 & 24 & 9 & 11 & 33 \\
\hline 2017 year & 30 & 24 & 12 & 17 & 40 \\
\hline
\end{tabular}

Source: author's own research

In order to determine the working capital management strategy, the management efficiency ratios were calculated for the most important components shaping the level of net working capital. The results are presented in Table 3.

Table 4 Turnover ratios ( in days) of selected elements affecting working capital

\begin{tabular}{|c|c|c|}
\hline Receivables rotation & $\bar{x}$ & Me \\
\hline 2015 year & 49.8 & 48.0 \\
\hline 2016 year & 59.0 & 54.0 \\
\hline 2017 year & 59.9 & 56.0 \\
\hline Liabilities rotation & $\bar{x}$ & Me \\
\hline 2015 year & 60.8 & 46.5 \\
\hline 2016 year & 69.6 & 61.5 \\
\hline 2017 year & 83.6 & 68.5 \\
\hline Inventory rotation & $\bar{x}$ & Me \\
\hline 2015 year & 36.9 & 35.0 \\
\hline 2016 year & 41.0 & 38.5 \\
\hline 2017 year & 43.6 & 38.0 \\
\hline
\end{tabular}

Source: author's own research

When assessing the dynamics of revenues and costs, in $85 \%$ of analyzed enterprises a faster increase in revenues over costs was observed.

\section{CONCLUSION}

The analysis conducted indicates the use of a safe working capital management strategy. The optimal level of current and good liquidity ratios, as well as operating cycle and cash conversion rates, indicate moderate strategies. The analysis of the conversion cycle of receivables from customers and liabilities to suppliers also indicates a moderate strategy. And, above all, the low stock turnover ratio. It is also positive that the change in the dynamics of sales revenues over the change in operating expenses should be more significant. If the owners of enterprises decide to leave profit in enterprises, then the equity in the structure of liabilities will increase. This change will reduce the demand for net working capital. The results of selected indicators indicate that enterprises analyzed for aluminum pressure foundries apply moderate - conservative strategies of working capital management. The presented working capital management strategy for the group of companies in question is optimal. 


\section{REFERENCES}

[1] PORTER, Michael E. Porter o konkurencji. Warszawa: PWE, 2000, p. 116.

[2] ENQVIST, Julius., GRAHAM, Michael and NIKKIINEN, Jussi. The impact of working capital management on firm profitability in different business cycles: evidence from Finland. Research in International Business and Finance. 2014. vol. 32, pp. 36-49.

[3] VAHID, Khanquah, ELHAM, Ghanavati., MOHSEN, Khosroshahi Akbari and MOHAMMADREZA, Ebrati. Working capital management and corporate performance: evidence from iranian companies. Procedia Social Behavioral Sciences. 2012. vol. 62, pp. 1313-1318.

[4] ZIMON, Grzegorz and ZIMON, Dominik, The Impact of Quality Management Systems on Financial Liquidity in Companies in Group Purchasing Organizations, WSEAS Transactions on Business and Economics. 2019. vol. 16, pp. 163-170.

[5] BEI Zhao. and WIJEWARDANA Withanage Percy. Working capital policy practice: evidence from Srilankan companies. Procedia Social Behavioral Sciences. 2012. vol. 40, pp. 695-700.

[6] MUN, Sung Gyun., JANG, Soo Cheong. Working capital, cash holding, and profitability of restaurant firms. International Journal Hospitality Management. 2015. vol. 48, pp. 1-11.

[7] KIESCHNICK, Robert., LAPLANTE, Mark. and MOUSSAWI, Rabith. Working capital management and shareholders wealth. Review of Finance. 2013. vol. 17 (5), pp. 1827-1852.

[8] DELOOF, Marc. and JEGERS, Marc. Trade credit, product quality, and Intra Group Trade: Some European evidence. Financial Management. 1996. vol. 25, pp. 33-43.

[9] WANG, Yung-Jang. Liquidity management, operating performance and corporate value: evidence from Japan and Taiwan. Journal of Multinational Financial Management. 2002. vol. 12(2), pp. 159-169.

[10] DING, Sai., GUARIGLIA, Alessandra. and KNIGHT, John. Investment and financing constraints in China: does working capital management make a difference? Journal of Banking \& Finance. 2013. vol. 37 (5), pp. 1490-1507.

[11] DELOOF, Marc. Does working capital management affect profitability of Belgian firms? Journal of Business Finance \& Accounting. 2003. Vol. 30, pp. 573-587.

[12] GARCIA-TERUEL, Pedro Juan. and MARTINEZ-SOLANO, Pedro. Effects of working capital management on SME profitability. International Journal of Managerial Finance. 2007. Vol. 3 (2), pp.164-177.

[13] SHIN, Hyuan Han. and SOENEN, Luc. Efficiency of working capital and corporate profitability. Financial Practice Education. 1998. vol. 8 (2), pp. 37-45.

[14] LAZARIDIS, loannis. and TRYFONIDIS, Dimitros. Relationship between working capital management and profitability of listed companies on the Athens Stock Exchange. Journal Financial Management Analysis. 2006. vol. 19 (1), pp. 26-35.

[15] ZIMON Dominik. and ZIMON Grzegorz. The Impact of Implementation of Standardized Quality Management Systems on Management of Liabilities in Group Purchasing Organizations. Quality Innovation Prosperity. 2019. vol 23, no. 1 (2019), pp 60-73. 